\title{
Archaeological Investigations of the City of San Antonio Nursery and San Antonio Zoo Eagle Railroad Tract Realignment Project, Bexar County, Texas
}

Antonia L. Figueroa

Center for Archeological Research, University of Texas at San Antonio

Follow this and additional works at: https://scholarworks.sfasu.edu/ita

Part of the American Material Culture Commons, Archaeological Anthropology Commons, Environmental Studies Commons, Other American Studies Commons, Other Arts and Humanities Commons, Other History of Art, Architecture, and Archaeology Commons, and the United States History Commons

Tell us how this article helped you.

This Article is brought to you for free and open access by the Center for Regional Heritage Research at SFA ScholarWorks. It has been accepted for inclusion in Index of Texas Archaeology: Open Access Gray Literature from the Lone Star State by an authorized editor of SFA ScholarWorks. For more information, please contact cdsscholarworks@sfasu.edu. 


\section{Archaeological Investigations of the City of San Antonio Nursery and San Antonio Zoo Eagle Railroad Tract Realignment Project, Bexar County, Texas}

\section{Creative Commons License}

\section{(c) (1) \&}

This work is licensed under a Creative Commons Attribution-NonCommercial 4.0 International License 


\section{Archaeological Investigations of the City of San Antonio Nursery and San Antonio Zoo Eagle Railroad Tract Realignment Project, Bexar County, Texas}

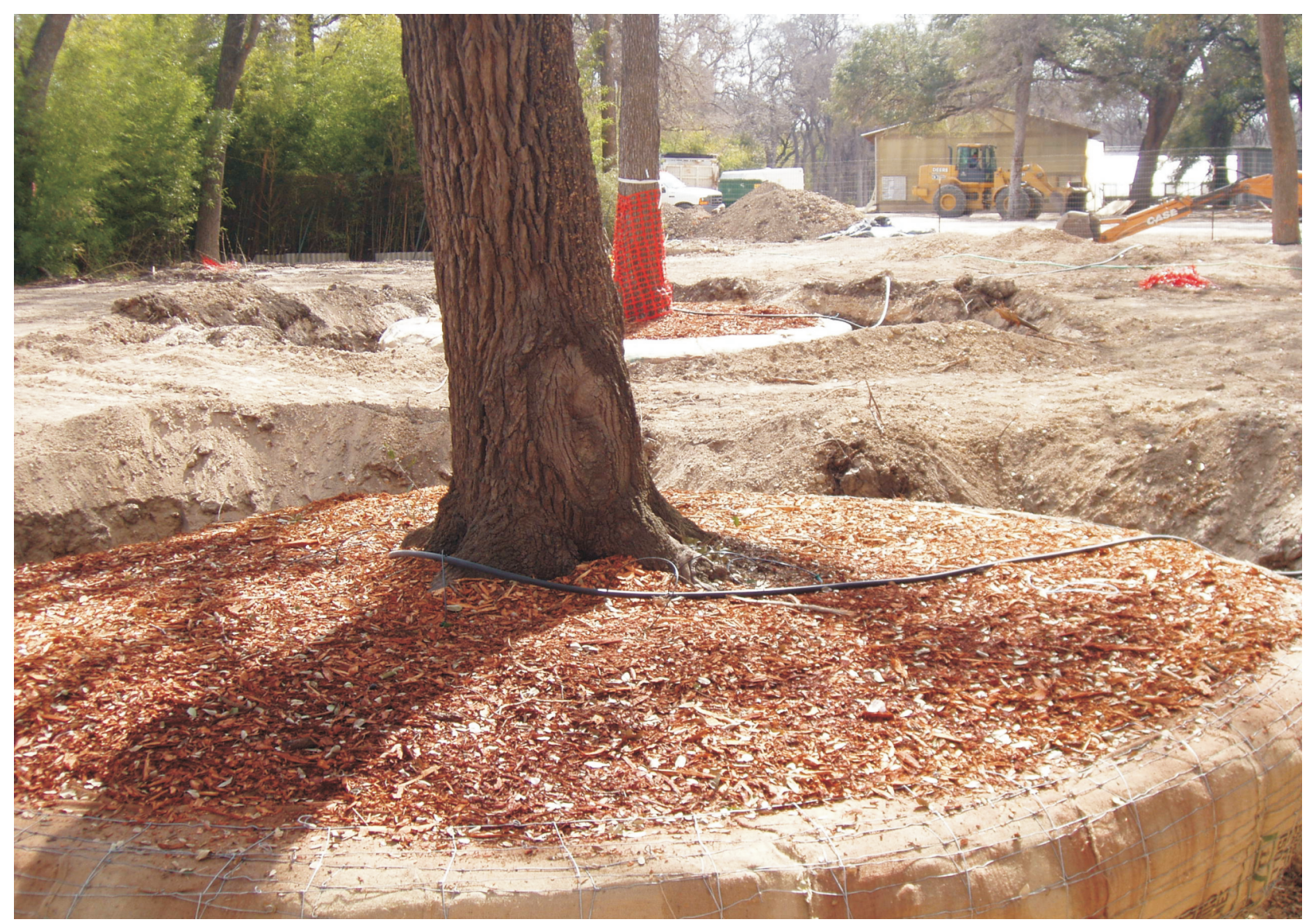

by

Antonia L. Figueroa

Prepared for:

San Antonio Parks and Recreation Department P.O. Box 839966

San Antonio, Texas 78283

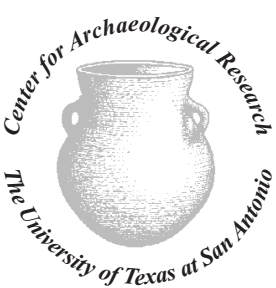

(C)2008
Prepared by:

Center for Archaeological Research The University of Texas at San Antonio Archaeological Report, No. 385 


\title{
Archaeological Investigations of the City of San Antonio Nursery and San Antonio Zoo Eagle Railroad Tract Realignment Project, Bexar County, Texas
}

\author{
by
}

Antonia L. Figueroa

Texas Antiquities Committee Permit No. 4647

Principal Investigator

Steve A. Tomka

Prepared for:

San Antonio Parks and Recreation Dept.

P.O. Box 839966

San Antonio, Texas 78283

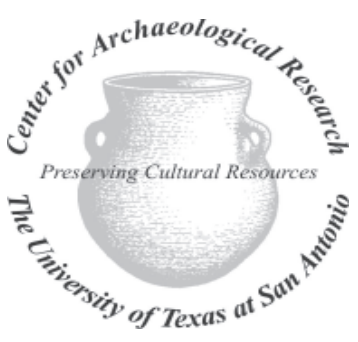

(C) 2008
Prepared by:

Center for Archaeological Research The University of Texas at San Antonio Archaeological Report No. 385 



\begin{abstract}
:
The Center for Archaeological Research (CAR) at The University of Texas at San Antonio (UTSA) conducted mechanical augering on land that was used for the former City of San Antonio Nursery and Parks and Maintenance Facility. Furthermore, a surface inspection of the San Antonio Zoo Eagle mini-track proposed re-alignment was also conducted. During investigations prehistoric site 41BX1773 was recorded in the northern section of the APE. Only one piece of fire-cracked rock and a railroad spike were collected during the surface inspection along the proposed San Antonio Zoo Eagle re-alignment. Archaeological investigations were conducted under Texas Antiquities Permit No. 4647.
\end{abstract}

CAR recommends that impacts to site 41BX1773 should be avoided and the re-alignment of the San Antonio Zoo Eagle train track may proceed as planned.

All materials recovered during the investigations and all project related documents are curated at the Center for Archaeological Research. 


\section{Table of Contents:}

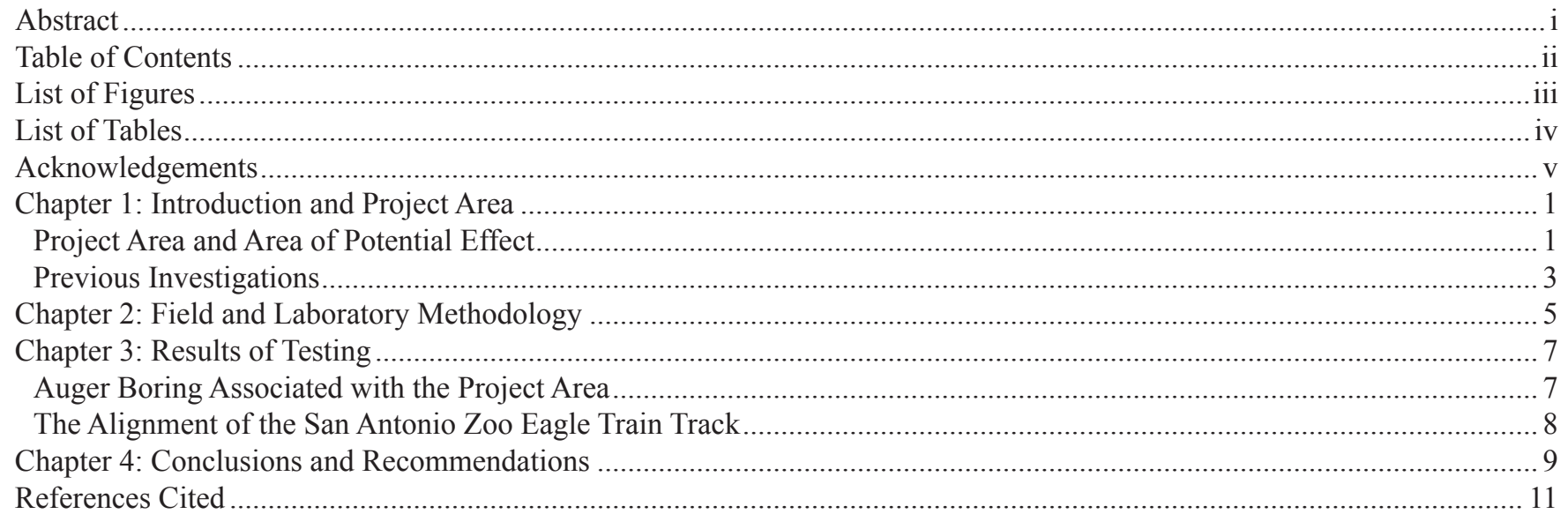




\section{List of Figures:}

Figure 1-1. The project area located in San Antonio, Bexar County, Texas.

Figure 1-2. The project area and Area of Potential Effect with auger tests and shovel tests............................................ 2

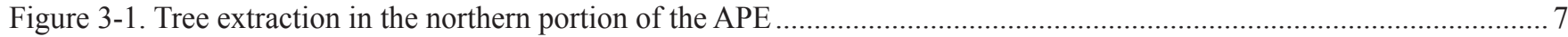

Figure 3-2. The proposed route for the re-alignment of San Antonio Zoo Eagle train railroad. ............................................ 8 


\section{List of Tables:}

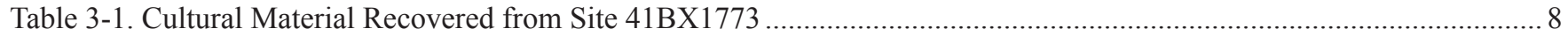

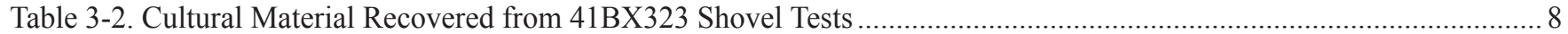




\section{Acknowledgements:}

The author gives special thanks to the field crew composed of Cyndi Dickey, Jon Dowling, Lindy Martinez and Jason Perez. Marybeth Tomka oversaw all lab processing and curation. Bruce Moses produced figures and served as Technical Editor for this report. Dr. Steve Tomka served as Principal Investigator. Thanks also to Bill Pennell with the City of San Antonio Parks and Recreation Department who aided with field logistics and project specifics. Other individuals who were an integral part of the project included: Kim Monroe with Lake/Flato Architects, Kay Hindes with the City of San Antonio Historical Preservation Office, Sarah Weston with Project Control and Mark Denton with the Texas Historical Commission. Alamo Backhoe Services provided the mechanical equipment for the field project. 



\section{Chapter 1: Introduction and Project Area}

This document summarizes the archaeological investigations conducted by the Center for Archaeological Research (CAR) of The University of Texas at San Antonio (UTSA) on February 4th, 5th and April 1, 2008. CAR was contracted by the City of San Antonio to provide archaeological services in association with the former City of San Antonio Nursery and Parks and Recreation Maintenance Facility and the realignment of a segment of the San Antonio Zoo Eagle train track in San Antonio, Bexar County, Texas (Figure 1-1). The archaeological services provided by CAR included: 1) mechanical auger boring of the former City nursery and maintenance facility (where reforestation of trees is planned) to search for hitherto undocumented archaeological deposits; 2) surface reconnaissance of the proposed re-alignment of the San Antonio Zoo Eagle train track; 3) analysis of any and all artifacts recovered during the field work and their preparation for curation at CAR's curatorial facility.

\section{Project Area and Area of Potential Effect}

The project area is located south of the San Antonio River, south of the Tuleta Drive and Avenue B intersection, adjacent to the Witte Museum (Figure 1-2). Proposed improvements include tree relocations and planting for reforestation of the area. The APE is a 3-acre tract that formerly served as the City of San Antonio Nursery and Parks and Recreation Maintenance Facility. The corridor of the proposed realignment for the San Antonio Zoo Eagle train track is approximately 140 meters long and approximately two meters wide. The proposed train track alignment is within the limits of site 41BX323, a portion of the site that was tested by CAR (Figueroa and Dowling 2007). The track installation will not require any grading and no direct subsurface impacts will occur to 41BX323.
Archaeological investigations were conducted under Texas Antiquities Permit No. 4647. Antonia L. Figueroa and Jon Dowling served as the Project Archaeologists during the field investigations. Steve A. Tomka served as the Principal Investigator.

As a result of archaeological investigations, CAR excavated 25 mechanical auger bores in the former City of San Antonio nursery and maintenance grounds where reforestation will occur (Figure 1-2). During auger boring, prehistoric cultural material was identified and recorded on the northern portion of the Area of Potential Effect (APE) and assigned the trinomial 41BX1773. A surface inspection of the corridor for the proposed re-alignment of the San Antonio Zoo Eagle train track also was conducted.

The land impacted by the project is owned by the City of San Antonio, a political subdivision of the State of Texas. As such, the project has to comply with State Historic Preservation laws and specifically the mandates of the Antiquities Code of Texas and falls under the oversight of the Texas Historical Commission.

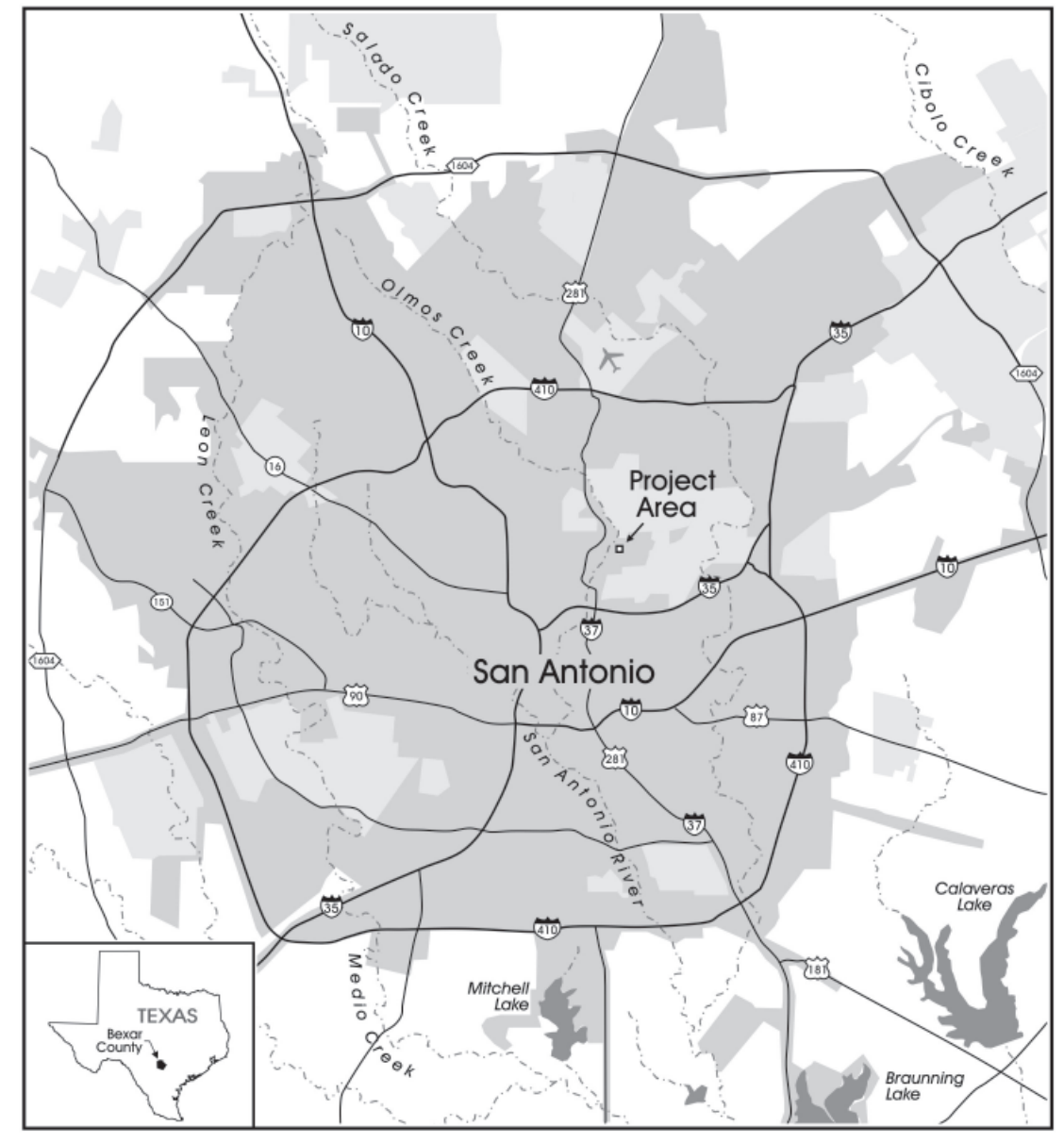

Figure 1-1. The project area located in San Antonio, Bexar County, Texas. 


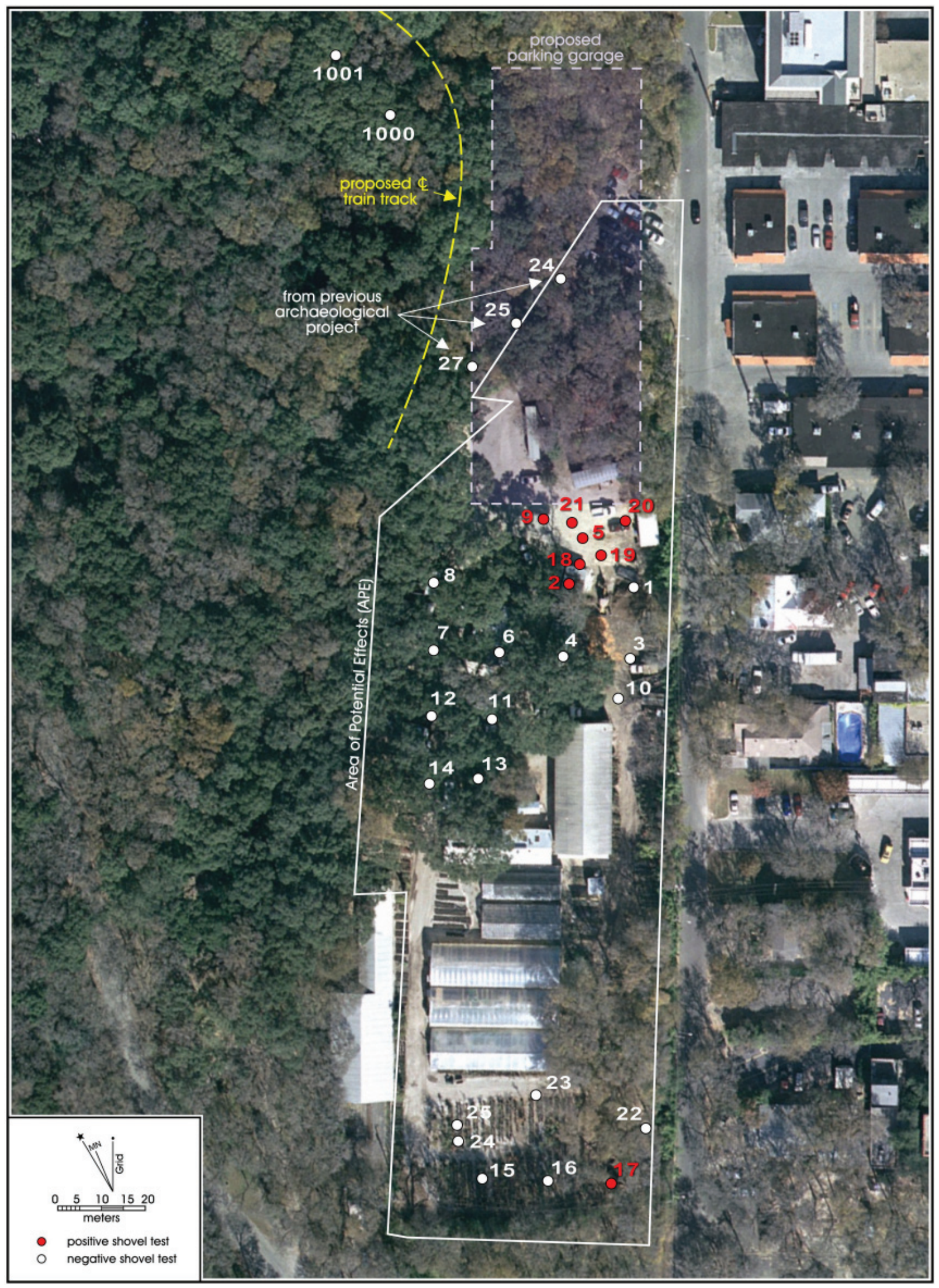

Figure 1-2. The project area and Area of Potential Effect with auger tests and shovel tests. 


\section{Previous Investigations}

CAR conducted eligibility testing on a previously uninvestigated portion of site 41BX323 in 2007 (Figueroa and Dowling 2007) in association with the proposed Brackenridge parking garage facility. CAR concluded that, the cultural material recovered during excavations likely represents a Late Prehistoric to Archaic occupation of the site. CAR identified no significant cultural materials, within the tested portion of the site that would contribute to the understanding of prehistoric Texas. Negative shovel tests located north of the Park and Recreation Facility (the current project areas) suggest that the boundary of site $41 \mathrm{BX} 323$ does not extend under the parking lot or onto the current APE. Therefore, CAR recommended no additional archaeological investigations.

Following the review of the draft final report, the Texas Historic Commission (THC) reviewer, Mark Denton, requested that the City Parks and Recreation Department coordinate with the THC regarding the movement of the maintenance facility found within the boundaries of the project area. In addition, the THC requested that Lake/Flato Architects coordinate with the THC regarding the re-alignment of the mini-rail road from within the footprint of the planned parking facility. Since the new location will fall within the limits of site 41BX323, it was paramount that no subsurface disturbances occur during the reinstallation of the San Antonio Zoo Eagle train tract. 



\section{Chapter 2: Field and Laboratory Methodology}

As part of CAR's archaeological investigations, auger tests and shovel testing methods were implemented. The auger bores were positioned on a $15-\mathrm{m}$ grid and were mechanically excavated with a 12 " auger bit to a depth of $120 \mathrm{cmbs}$. All soils from the auger holes were screened through $1 / 4$ inch hardware cloth. Four of the auger tests were excavated in three $40-\mathrm{cm}$ levels to a depth of $120 \mathrm{cmbs}$. Observations regarding the presence of absence of artifacts were recorded on forms that included a description of soils and any inclusions or disturbances encountered. All artifacts collected during auger testing were bagged and processed for analysis at CAR. All auger test locations were recorded with a GPS unit.

A surface reconnaissance was conducted along the proposed re-alignment of the San Antonio Zoo Eagle train track. Due to the low surface visibility, two shovel tests were excavated along the proposed alignment. Shovel tests were $30 \mathrm{~cm}$ in diameter and excavated to a depth of $60 \mathrm{~cm}$ below surface (cmbs). They were excavated in $10-\mathrm{cm}$ increments, and all soil from each level was screened through $1 / 4$-inch hardware cloth. All encountered artifacts were recovered and tagged with appropriate provenience for laboratory processing, analysis, and curation. A shovel test form was completed in pencil for the two shovel tests. Data collected from each shovel test included the final excavation depth, a tally of all materials recovered from each $10-\mathrm{cm}$ level, and a brief soil description (texture, consistency, Munsell color, inclusions). Any additional observations considered pertinent were included as comments on the standard shovel test excavation form.

Subsequent to the shovel testing, a standard yard rake was used to remove leaf litter from the surface of the proposed train re-alignment corridor. The proposed alignment was traversed in order to surface collect any artifacts. When artifacts were encountered their location was recorded with a GPS unit.

The artifacts were brought to CAR's laboratory where they were processed and catalogued according to CAR's standard practices. Processing of recovered artifacts consisted of washing and sorting into appropriate categories (e.g., debitage, lithic tool). Artifacts were washed, air-dried, and stored in archival-quality bags. Acid-free labels were placed in all artifact bags. Each label displayed provenience information and a corresponding lot number laser printed or written in pencil. Artifacts were separated by class and stored in acid-free boxes identified with standard labels. The data were entered into a Microsoft Access database. All artifacts are permanently curated at CAR. 



\section{Chapter 3: Results of Testing}

\section{Auger Boring Associated with the Project Area}

Archaeological investigations of the 3 -acre tract resulted in 25 mechanical auger tests. Tree planting included the excavation and removal of trees from the far northern portion of the APE within the nursery area. Prior to archaeological investigations some trees had been prepped for removal resulting in large excavated areas (Figure 3-1). No auger tests were excavated in this area. The back-dirt and excavated areas associated with the tree removal were examined for artifacts but none were observed. Several building were in the process of being demolished during the field work, therefore, the south-central portion of the APE was not tested. The demolished buildings were non-historic. Moreover, two areas in the northern portion of the APE were identified for contaminated soils and avoided during archaeological excavations.
Out of the 25 auger excavations, eight were positive for cultural material (see Figure 1-2). Areas where the excavated trees (from the far northern portion of the APE) were to be replanted in the APE were identified prior to excavations and tested first (1, 3, 10, 7, 8 and 12). These areas were along the west and eastern margins of the APE. Auger tests in those areas were negative for cultural material and clearance was given to re-plant the trees.

\section{BX1773}

In the north-central portion of the APE, three auger excavations (2, 5, and 9) were positive for cultural material (burned rock, lithic debitage and lithic tools). Four additional auger tests were excavated within 5-m of the positive tests.

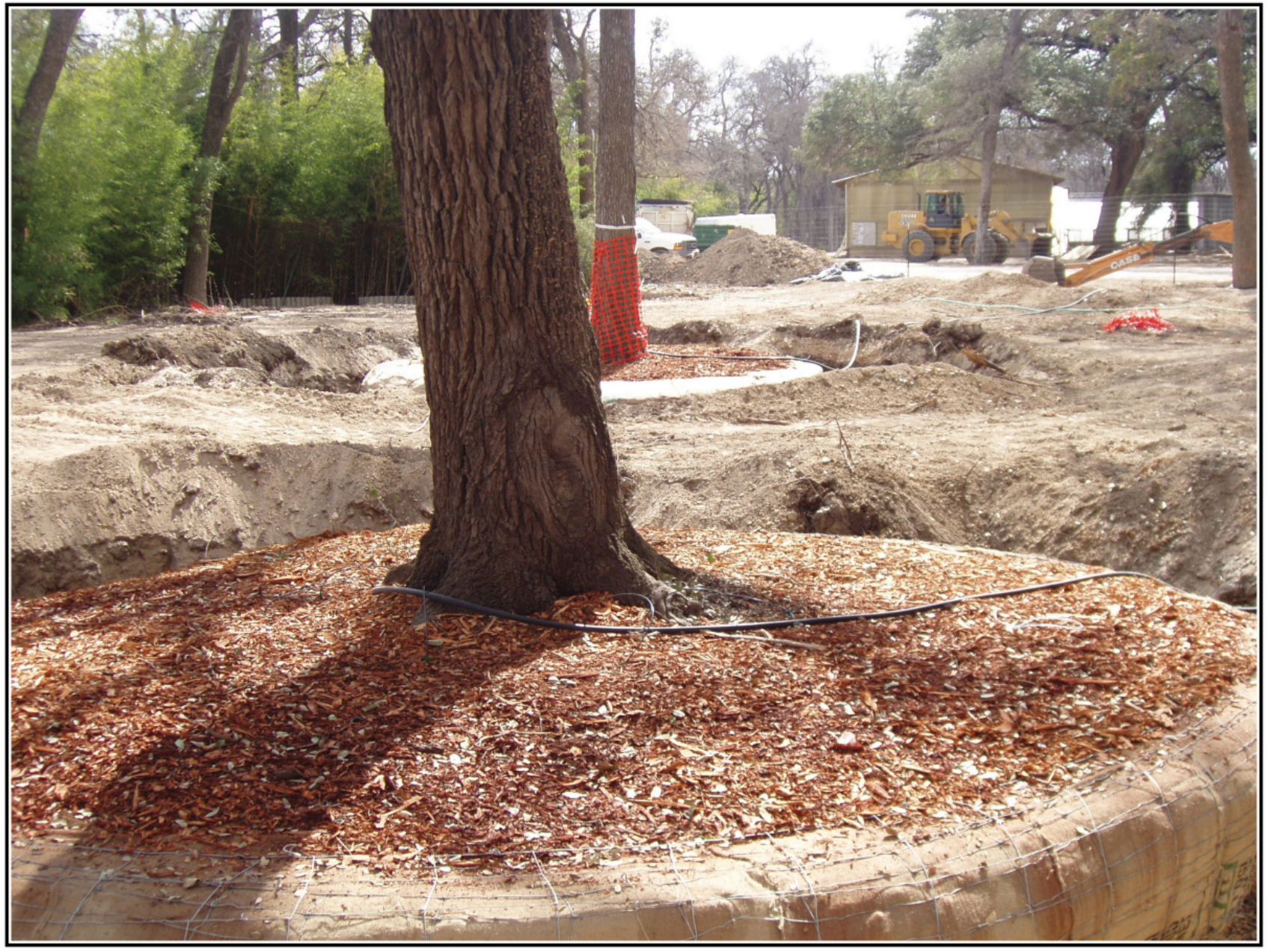

Figure 3-1. Tree extraction in the northern portion of the APE 
The additional auger tests were excavated in three $40 \mathrm{~cm}$ levels to obtain more detailed information on the vertical distribution of cultural materials. As a result, there were seven positive auger bores clustered within the northern $1 / 3$ rd of the nursery lot. Auger testing revealed 20 to $40 \mathrm{~cm}$ of gravel fill atop a clay matrix in this area. Cultural material (Table 3-1) consisted mostly of lithic debitage $(\mathrm{n}=10)$. Burned rock

Table 3-1. Cultural Material Recovered from Site 41BX1773

\begin{tabular}{|l|c|c|c|c|c|c|}
\hline Level & $\begin{array}{c}\text { Burned } \\
\text { rock }\end{array}$ & Debitage & $\begin{array}{c}\text { Debitage- } \\
\text { retouched }\end{array}$ & Glass & $\begin{array}{c}\text { Lithic } \\
\text { tools } \\
\text { and } \\
\text { cores }\end{array}$ & $\begin{array}{c}\text { Grand } \\
\text { Total }\end{array}$ \\
\hline $0^{*}$ & 3 & 2 & 1 & 1 & 2 & 9 \\
\hline $\begin{array}{l}1(0- \\
40 \mathrm{~cm})\end{array}$ & 0 & 1 & 0 & 0 & 0 & 1 \\
\hline $\begin{array}{l}2(40- \\
80 \mathrm{~cm})\end{array}$ & 1 & 5 & 0 & 0 & 0 & 6 \\
\hline $\begin{array}{l}3(80- \\
120 \\
\mathrm{~cm})\end{array}$ & 0 & 2 & 0 & 0 & 0 & 2 \\
\hline $\begin{array}{l}\text { Grand } \\
\text { Total }\end{array}$ & 4 & 10 & 1 & 1 & 2 & 18 \\
\hline
\end{tabular}

* material from auger tests excavated without levels

$(n=3)$ and lithic tools $(n=2)$ were also recovered but mostly from the first three auger tests that were not excavated in $40 \mathrm{~cm}$ levels. A trinomial request was submitted to the Texas Archeological Research Laboratory (TARL) and the site was given new trinomial 41BX1773. The site is small, measuring $17 \mathrm{~m}$ in length and $20 \mathrm{~m}$ in width. Cultural material extends to a depth of $1 \mathrm{~m}$ below surface.

After consultation with the City of San Antonio, no disturbances will occur on 41BX1773 and this portion of the proposed reforested area. If future work occurs in this area, the City will coordinate any proposed activities with the Texas Historical Commission. South of this cluster, no cultural deposits were found, with the exception of a flake contained within fill in one auger bore (17). Soils in the southern portion of the APE consisted of gravel fill to a depth of $20 \mathrm{cmbs}$, followed by a dark brown clay matrix.

\section{The Alignment of the San Antonio Zoo Eagle Train Track}

Surface visibility along the proposed train track alignment was $0 \%$ and therefore two shovel tests (STs) were excavated along a portion of the alignment which is within the site boundaries of site 41BX323 (Figure 3-2). A portion of the proposed alignment crosses into the areas tested by CAR (Figueroa and Dowling 2007) during the Brackenridge Parking Facility project. Cultural material was recovered from the shovel tests that included burned rock $(n=42)$ and lithic debitage $(n=32$; Table 3-2). Both STs contained cultural materials in the upper $10 \mathrm{~cm}$ level and down to $60 \mathrm{cmbs}$. Since the proposed alignment is within the boundaries of site 41BX323, there is probably no place where the tract can be moved without impacting the site. However, because installation impacts are anticipated to be only surface-related, on April 1st, the CAR staff cleared the vegetation that obscured ground surface visibility along the planned route of the train track. Subsequently, we mapped (with GPS units) and collected all surface artifacts. Only two artifacts, a railroad stake and a piece of fire-cracked rock, were present along the proposed route. Therefore, no impacts to surface cultural materials are anticipated from the proposed installation.

Table 3-2. Cultural Material Recovered from 41BX323 Shovel Tests

\begin{tabular}{|c|c|c|c|}
\hline Level & Burned Rock & Debitage & Grand Total \\
\hline $1(0-10 \mathrm{~cm})$ & 14 & 7 & 21 \\
\hline $2(10-20 \mathrm{~cm})$ & 9 & 5 & 14 \\
\hline $3(20-30 \mathrm{~cm})$ & 5 & 2 & 7 \\
\hline $4(30-40 \mathrm{~cm})$ & 2 & 1 & 3 \\
\hline $5(40-50 \mathrm{~cm})$ & 3 & 11 & 14 \\
\hline $6(50-60 \mathrm{~cm})$ & 9 & 6 & 15 \\
\hline Grand Total & 42 & 32 & 74 \\
\hline
\end{tabular}

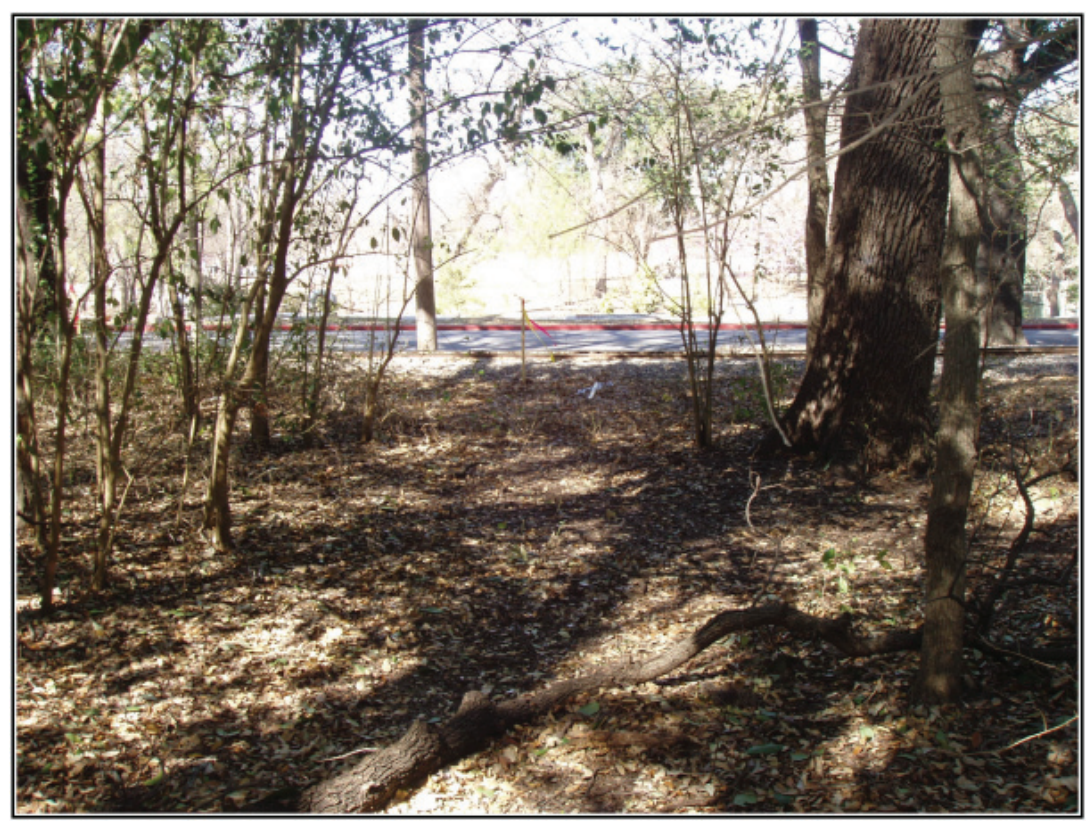

Figure 3-2. The proposed route for the re-alignment of San Antonio Zoo Eagle train railroad. 


\section{Chapter 4: Conclusions and Recommendations}

This document summarizes the archaeological investigations conducted by the Center for Archaeological Research of The University of Texas at San Antonio. Proposed improvements include reforestation of the former City of San Antonio Nursery and Parks and Recreation Maintenance Facility which will occur in a 3-acre tract. The proposed alignment for the San Antonio Zoo Eagle train track relocation was also investigated. Out of the 25 auger bores, eight (32\%) were positive for cultural material. One positive auger test (A17), located in the far southwest corner of the APE was recorded as an isolated find.

Seven of the positive auger tests were defined as 41BX1773. The site was covered with 20 to $40 \mathrm{~cm}$ of gravel fill. The cultural materials recovered from the site were burned rock, lithic debitage and tools. The materials were distributed from $40 \mathrm{~cm}$ bs to $120 \mathrm{~cm}$ bs. No temporal diagnostics were recovered and therefore the temporal affiliation of the deposits is not known. After consultation with the City of San Antonio, no disturbances will occur within site 41BX1773 and this portion of the reforested area. If future work occurs in this area, the City will coordinate any proposed activities with the Texas Historical Commission. During the surface inspection of the proposed corridor for San Antonio Zoo Eagle train track re-alignment only two artifacts were collected. Two shovel tests excavated along the alignment indicated subsurface deposits. However, since only two artifacts were encountered on surface and anticipated impacts are limited to the surface, we recommend the alignment for the proposed train track proceed as planned. 



\section{References Cited}

Figueroa, A. and J. Dowling

2007 Additional Phase II Testing at 41BX323 in Brackenridge Park, San Antonio, Bexar County, Texas. Archaeological Report, No. 377, Center for Archaeological Research, University of Texas at San Antonio. 
